\title{
SOlEARHYNCHUS KOSTYLEWI (MEYER, 1932) COMB. NOV. (ACANTHOCEPHALA: ECHINORHYNCHIDAE), a Rare parasite of Solea solea (PISCES: Soleidae) in the Gemlik Bay, Sea of Marmara
}

\author{
KVACH Y.**** \& OĞUZ M.C.****
}

\section{Summary:}

Paracanthocephaloides kostylewi (Meyer, 1932), a rare parasite of the common sole Solea solea, previously placed in the Arhythmacanthidae, is transfered to the genus Solearhynchus de Buron \& Maillard, 1985 of the family Echinorhynchidae as Solearhynchus kostylewi (Meyer, 1932) new comb., because its proboscis is armed by a single type of hooks, the posterior hook in each row is pinlike and with feebly developed root. The species is redescribed on the basis of newly collected material from the Gemlik Bay, Sea of Marmara. A key to the species of Solearhynchus is provided.

KEY WORDS : Acanthocephaloides, Arhythmacanthidae, Echinorhynchidae, Sea of Marmara, Solearhynchus.
Résumé : SOLEARHYNCHUS KOSTYLEWI (MeYER, 1932) COMB. NOv. (ACANTHOCEPHALA : ECHINORHYNCHIDAE), RARE PARASITE DE SOLEA solea (Pisces : Soleidae) de la Baie de Gemlik, Mer de Marmara

Paracanthocephaloides kostylewi (Meyer, 1932), un rare parasite de la sole commune Solea solea, précédemment placé dans la famille des Arhythmacanthidae, est transféré dans le genre Solearhynchus de Buron et Maillard, 1985 de la famille des Echinorhynchidae comme Solearhynchus kostylewi (Meyer, 1932) comb. nov., car sa trompe est armée par un seul type de crochets, le crochet postérieur de chaque rangée étant en forme d'épingle avec une racine faiblement développée. L'espèce est redécrite sur la base du matériel nouvellement collecté dans la Baie de Gemlik, Mer de Marmara. Une clé de l'espèce de Solearhynchus est proposée.

MOTS CLÉS : Acanthocephaloides, Arhythmacanthidae, Echinorhynchidae, Mer de Marmara, Solearhynchus.

\section{INTRODUCTION}

$\mathrm{F}$ ive acanthocephalan species, Solearbynchus soleae (Porta, 1905) de Buron \& Maillard, 1985 (Echinorhynchidae), Acanthocephaloides propinquus (Dujardin, 1845) Meyer, 1932, Paracanthocephaloides kostylewi (Meyer, 1932) Pichelin \& Cribb, 1999 (all Arhythmacanthidae), Longicollum pagrosomi Yamaguti, 1935 (Pomphorhynchidae), and Telosentis exiguus (von Linstow, 1901) Kostylew, 1926 (Illiosentidae), have been reported from fishes of the Sea of Marmara (Oğuz, 1991; Oğuz \& Kvach, 2006).

Paracanthocephaloides kostylewi is a rare parasite that infects the sole Solea solea (Linnaeus). All previous cases of the occurrence of this acanthocephalan are rather old and data on its morphology are rather scarce and incomplete (Kostylew, 1926; Chulkova, 1939;

\footnotetext{
* Odessa Branch of the Institute of Biology of the Southern Seas, NAS of Ukraine, Vul. Pushkinska 37, 65125 Odessa, Ukraine.

** Institute of Parasitology, Biology Centre of the Academy of Sciences of the Czech Republic, Branišovská 31, 37005 České Budějovice, Czech Republic.

**** Biology Department, Faculty of Science and Arts, Ataturk University, 25240 Erzurum, Turkey.

Correspondence: Yuriy Kvach.

Tel./Fax: +(38048) 7250918

E-mail: yuriy.kvach@gmail.com, kvach@localka.net
}

Osmanov, 1940; Chernyshenko, 1947; Rǎdulescu, 1948; Butskaya, 1952; Rădulescu \& Angelescu, 1973; Solonchenko, 1982; Florescu \& Ieniştea, 1984).

During a study of the helminth parasites of marine fish of the Sea of Marmara, Turkey, new material of P. kostylewi was found, which made it possible to redescribe this poorly known and fairly rare taxon and to discuss its taxonomic status.

\section{MATERIALS AND METHODS}

Three specimens (one male, two females) were sampled by MCO from the common sole S. solea in the coastal waters of the Gemlik Bay, Sea of Marmara $\left(40^{\circ} 22^{\prime} \mathrm{N}, 28^{\circ} 52^{\prime} \mathrm{E}\right)$. The parasites were fixed in acetic acid/formaldehyde/alcohol solution (AFA). Then the worms were stained with Mayer's carmalum and mounted in Canada balsam. Measurements of body are given in millimetres ( $\mathrm{mm}$ ), but all other measurements are given in micrometres $(\mu \mathrm{m})$. Figures were prepared with the aid of a camera lucida.

The type specimens of $P$. kostylewi are not available. For the comparative study the type specimens of Solearhynchus soleae deposited in the Muséum National d'Histoire Naturelle, Paris, were studied (Cat. Nos. 475 HF H1 105-106, samples in alcohol). 


\section{RESULTS}

\section{Family ECHINORHYNCHIDAe COBbOLD, 1876}

SOLEARHYNCHUS KOSTYLEWI (MEYER, 1932) COMB. NOV.

Syns.: Echinorhynchus propinquus Dujardin, 1845 sensu Kostylew (1926); Acanthocephaloides kostylewi Meyer, 1932; Paracanthocephaloides kostylewi (Meyer, 1932) Pichelin \& Cribb, 1999.

Description: body smooth, 7.3 (6.5-7.9) long and 0.9 (0.7-1.0) wide; anterior part wider than posterior one (Fig. 1). Lemnisci 642 (504-824) long. Two sensory papillae on neck (Fig. 2). Brain ganglion on base of proboscis receptacle. Proboscis receptacle 642.7 (616-672) long. Proboscis cylindrical, 333 (240-400) long, armed with 16 longitudinal rows, 5-6 hooks in each row (Fig. 2). All hooks of similar type. Largest hooks in middle part of proboscis, 59 (40-80) long. Posterior hook in each row smallest, 27 (20-30) long, pinlike, with feebly developed root (Fig. 2). Hook roots with anteriorly direc- ted processes. Basal part of hook blades covered by tegument.

Male ( $\mathrm{n}=1)$ : $6.6 \mathrm{~mm}$ long and $0.9 \mathrm{~mm}$ wide (Fig. 1). Lemnisci 560 and 624 long. Proboscis 360 long, proboscis receptacle 672 long. Genital system occupies $60 \%$ of posterior part of trunk. Testes (anterior $240 \times 320$; posterior $240 \times 312$ ) located in middle part of body, at distance from cement glands. Cement glands six, in tandem, pyriform. Saefftigen's pouch well developed. Genital pore terminal.

Female $(\mathrm{n}=2): 7.5-7.9 \mathrm{~mm}$ long and 0.7-1.0 mm wide (Fig. 1). Lemnisci 504-824) long. Proboscis 240-400 long, proboscis receptacle 616-640 long. Uterine bell with well-developed selector cells. Eggs $(n=15) 57$ $(50-65) \times 14.2(12.5-17.5)$ (Fig. 3) with polar prolongations. Genital pore subterminal.

Type host: the snouted sole Pegusa lascaris (Risso, 1810) (Pleuronectiformes).

Other hosts: common sole Solea solea (Pleuronectiformes), horse mackerel Trachurus trachurus (Linnaeus, 1758) (Perciformes); grass goby Zosterisessor
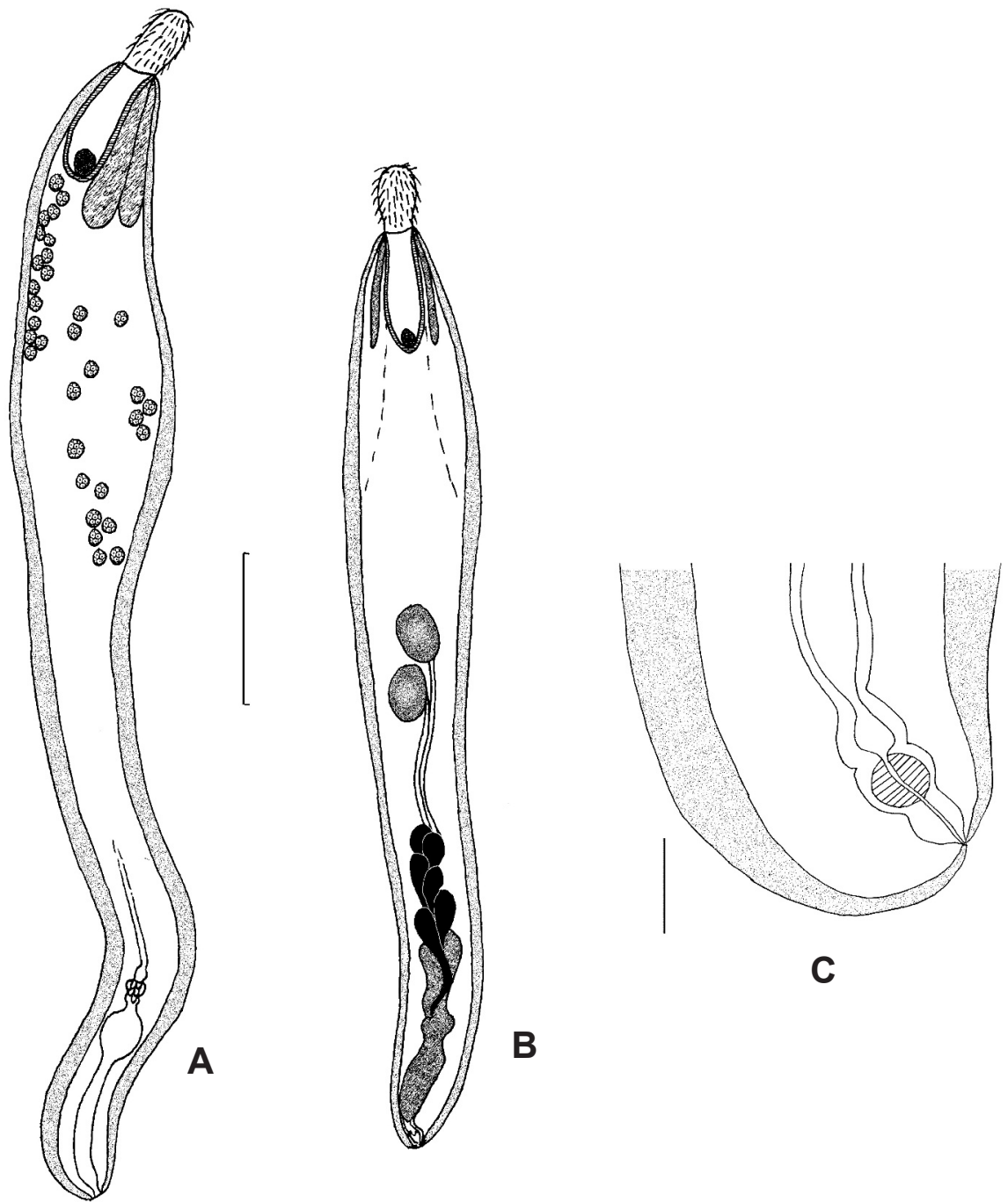

Fig. 1. - Solearbynchus kostylewi (Meyer, 1933) comb. nov. From Solea solea, Turkey. A. Female in toto; B. Male in toto; C. Vagina. For A, B, scale-bar: $1,000 \mu \mathrm{m}$; for $\mathrm{C}$, scale bar: $100 \mu \mathrm{m}$.

B 


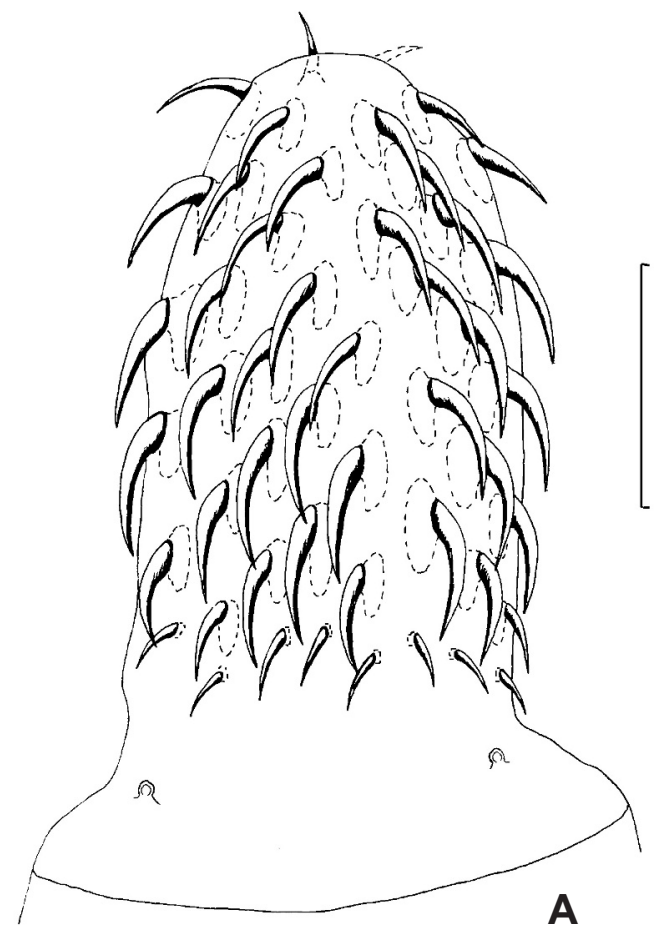

Fig. 2. - Proboscis (A) of male Solearhynchus kostylewi and a hooks row (B). Scale-bar: $100 \mu \mathrm{m}$.

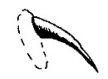

?.1

1
$\vdots$
$\vdots$

i)

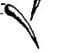

B

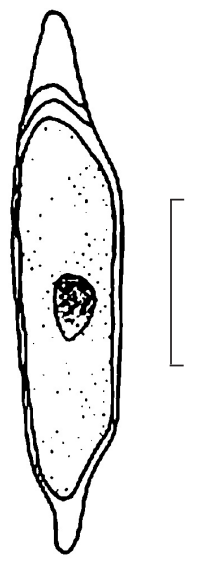

Fig. 3. - Egg. Scale-bar: $10 \mu \mathrm{m}$

ophiocephalus (Pallas, 1814) (Perciformes); stargazer Uranoscopus scaber Linnaeus, 1758 (Scorpeniformes); flounder Platichthys flesus (Linnaeus, 1758) (Pleuronectiformes).

Site: intestine.

Distribution: Sevastopol Bay (Kostylew, 1926; Osmanov, 1940; type locality). Other localities: Gulf of Odessa (Chernyshenko, 1947), North-Western Black Sea (Rǎdulescu, 1948; Butskaya, 1952; Rădulescu \& Angelescu,

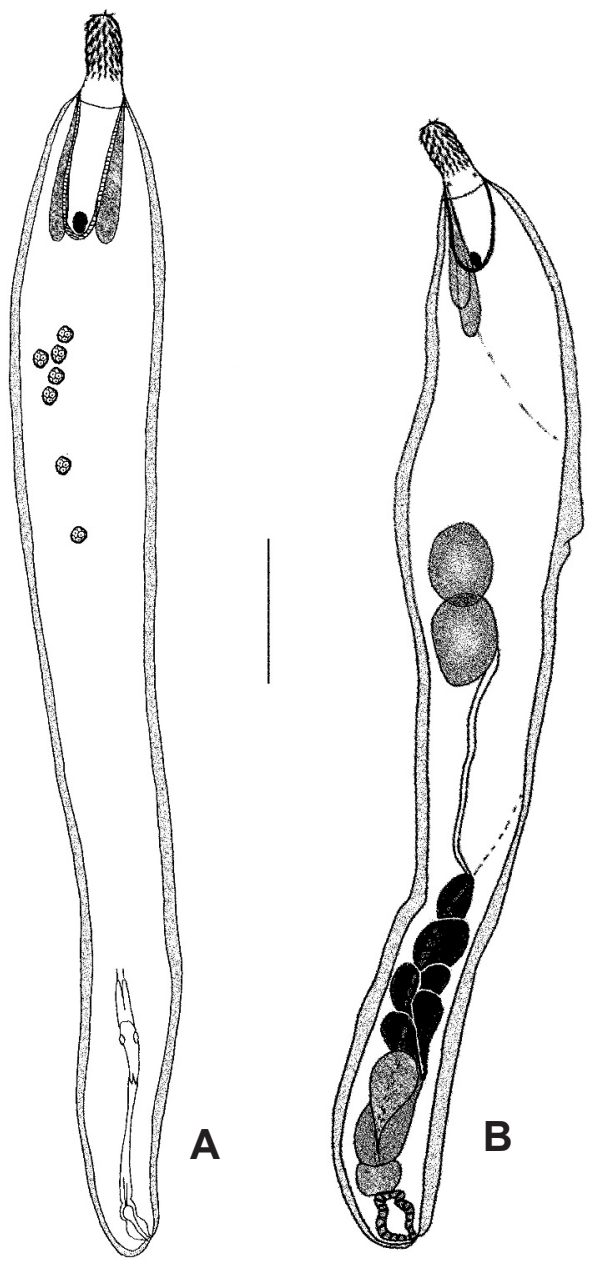

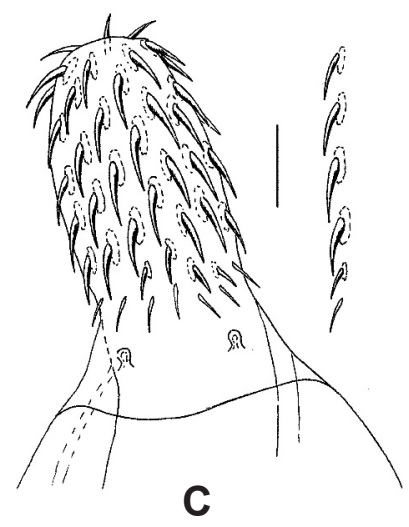
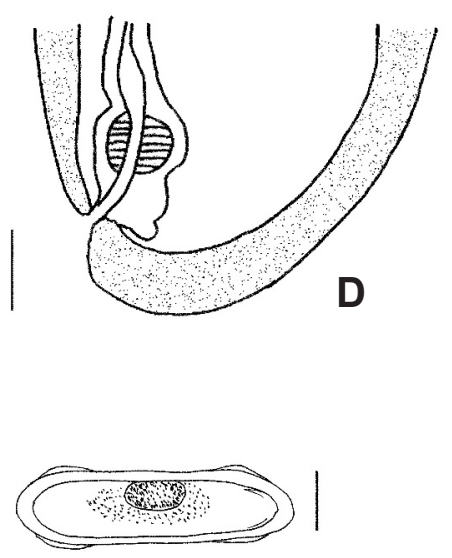

E
Fig. 4. - Solearbynchus soleae (Porta, 1905) de Buron \& Maillard, 1985. From Pegusa impar, France. Type specimens (samples in alcohol), Muséum National d'Histoire Naturelle, Paris, Cat. Nos. 475 HF H1 105106. A. Female in toto; B. Male in toto; C. Proboscis and a hook row; D. Vagina; E. Egg. For A, B, scalebar: $1,000 \mu \mathrm{m}$; for $\mathrm{C}, \mathrm{D}$, scale-bar: $100 \mu \mathrm{m}$; for E, scale bar: $10 \mu \mathrm{m}$. 
1973; Florescu \& Ieniştea, 1984), Caucasus near-shore (Chulkova, 1939), Kerch Strait (Solonchenko, 1982), Gemlik Bay, Sea of Marmara (this study, new locality). Deposition of voucher specimens: Parasitological Collection of Ataturk University, Erzurum, Turkey (Cat. no. MP9016A1-3).

\section{DISCUSSION}

T his species was first reported off the Crimean coast in the snouted sole Pegusa nasuta by Kostylew (1926) under the name Echinorbynchus propinquus Dujardin, 1845. It was then described as a new species, Acanthocephaloides kostylewi, by Meyer (1932) based on a drawing from Kostylew (1926) and its validity was accepted by Petrochenko (1956), Yamaguti (1963) and Golvan (1968). However, Amin (1985) synonymized this species with Acanthocephaloides propinquus (Dujardin, 1845). At the beginning this species was put in Echinorhynchidae (Meyer, 1932; Petrochenko, 1956; Yamaguti 1963), but then moved to Arhythmacanthidae (Golvan, 1968). Bray et al. (1988) supposed that this species possibly may belong to Paracanthocephaloides Golvan, 1969 because of the lack of tegumental spines. Later Pichelin \& Cribb (1999) note Paracanthocephaloides kostylewi (Meyer, 1932) Bray, Spencer Jones \& Lewis, 1988 when reviewing the subfamily Paracanthocephaloidinae in Arhythmacanthidae. However, the characteristic of the family Arhythmacanthidae is different types of hooks on the proboscis (see Golvan, 1969).

Our observations indicate that the proboscis hooks are of one type (see Fig. 2), as typical for the Echinorhynchidae (Petrochenko, 1956; Golvan, 1968). According to O`guz \& Kvach (2006), the posterior hooks are unrooted, but the present study shows that $S$. kostylewi has bad developed root, as is presented in Echinorhynchidae too. A study of the type specimens of Solearbynchus soleae has revealed that the posteriormost hooks of each longitudinal row is pin-like and has a feebly developed root (Fig. 4). The hooks of S. soleae have roots with the anteriorly-directed appendices (see Fig. 4 in this study, Fig. 2 in de Buron \& Maillard, 1985). Also the six linearly arranged cement glands, location of the genital pore, two sensor papillae on the neck, and the brain ganglion in the base of the proboscis receptacle are typical characters of the genus Solearhynchus as defined by de Buron \& Maillard (1985). In contrast to $S$. soleae, which has a proboscis armed with 12 rows of 5-6 hooks in each (Porta, 1905; Petrochenko, 1956; Golvan, 1969; de Buron \& Maillard, 1985), S. kostylewi has a proboscis armed with 16 rows of 5-6 hooks (Fig. 2). Another difference between these two species is in the morphology of the eggs, which have four lateral-longitudinal swellings without polar prolongations in $S$. soleae, whereas those of $S$. kostylewi possess polar prolongations (Figs 3, 4).

S. kostylewi was found in the snouted sole P. nasuta by Florescu \& Ieniştea (1984) and Rădulescu (1948) in the Black Sea and Solonchenko (1982) in the Kerch Strait. Chernyshenko (1947) reported this species as Acanthocephaloides propinquus from the snouted sole from the Gulf of Odessa. Also Chulkova (1939) and Osmanov (1940) noted the acanthocephalans from soles as A. propinquus de Buron et al. (1986) noted that S. kostylewi is a "small species", which "reproductive male structures occupy only the posterior third of the body". However, we found that the testes occupy the central part of the body. This characteristic was also illustrated by Kostylew (1926). The size of the body is relatively large, agreeing with the data of Chernyshenko (1947) who reports 4,500-10,000 $\mu \mathrm{m}$ length. To facilitate identification of species of Solearbynchus, parasites of Soleidae, a simple key based on morphological characteristics is provided.

Key to species of Solearbynchus:

1(2). Proboscis armed with 12 rows of hooks of 5-6 each; eggs with four lateral-longitudinal swellings........ ....S. soleae (Porta, 1905) de Buron \& Maillard, 1985 2(1). Proboscis armed with 16 rows of hooks of 5-6 each; eggs with polar prolongation..................S. kostylewi (Meyer, 1932) comb. nov.

\section{ACKNOWLEDGEMENTS}

W e thank Dr Rodney Bray (The Natural History Museum, London, UK) and Dr Tomáš Scholz (Institute of Parasitology, BC AS CR, České Budějovice, Czech Republic) for their valuable comments, and also Dr Richard A. Heckmann (Brigham Young University, Provo, Utah, USA) and Zlatka Dimitrova (Thracian University, Stara Zagora, Bulgaria) for their help to get the necessary published papers. This study was partly supported by the Institute of Parasitology (projects Nos Z60220518 and LC522). The study of the type material of Solearbynchus soleae was supported by project FR-TAF-4510 of the programme SYNTHESYS funded by the European Communities.

\section{REFERENCES}

Amin O.A. Classification, in: Biology of the Acanthocephala. Crompton D.W.T. \& Nickol B.B. (eds.), Cambridge University Press, Cambridge, London, New York, New Rochelle, Melbourne, Sydney, 1985, 27-72.

Bray R.A., Spencer Jones M.E. \& LewIs J.W. Acanthocephaloides cyrusi n. sp. (Acanthocephala: Arhythmacanthidae) from southeast African teleost fishes. Systematic Parasito$\log y, 1988,12,109-116$. 
Buron I. DE \& Maillard C. Acanthocéphales de Pleuronectiformes méditerranéens (Golf du Lion). 1. Création du genre Solearhynchus (Palaeacanthocephala). Annales de Parasitologie Humaine et Comparée, 1985, 60, 205-210.

Buron I. De, Renaud F. \& Euzet L. Speciation and specificity of acanthocephalans. Genetic and morphological studies of Acanthocephaloides geneticus sp. nov. parasitizing Arnoglossus laterna (Bothidae) from the Mediterranean littoral (Sète, France). Parasitology, 1986, 92, 165-171.

BuTSKAYA N.A. Parazitofauna chernomorskih promyslovyh ryb predustyevogo prostranstva Dunaya. Trudy Leningradskogo obshchestva yestestvoispytateley, 1952, 71 (4), 30-52.

CHERNYSHENKO A.S. Materialy po parazitofaune ryb Odesskogo zaliva. PhD Thesis, University of Odessa, Odessa, 1947, 223 p.

Chulkova V.N. Parazitofauna ryb okrestnostey g. Batumi. Uchenye zapiski Leningradskogo gosudarstvennogo universiteta, Ser. Biol. Nauk., 1939, 43 (11), 21-32.

Florescu B.-I., Ieništea M.-A. Aperçu sur les Acanthocéphales de Roumanie (Acanthocephala). Travaux du Muséum d'Histoire Naturelle "Grigore Antipa", 1984, 25, 7-46.

Golvan Y.J. Systématique des acanthocéphales (Acanthocephala Rudolphi 1801). L'Ordre de Palaeacanthocephala Meyer 1931. La superfamille de Echinorhynchoidea (Cobbold 1876) Golvan et Houin 1963. Mémoires du Muséum Nationale d'Historie Naturelle, Série A, 1969, 57, 1-373.

Kostylew N.N. Zur Kenntnis der Acanthocephalen der Fische des Schwarzen Meeres. Zoologischer Anzeiger, 1926, 67, $177-183$

MeYer A. Acanthocephala, in: Klassen und Ordnungen des Tierreichs, Volumen 4, Buch 2. Bronns H.G. (ed.), Akademische Verlagsgesellschaft MBH, Leipzig, 1932, 582 p.

Ǒ̌uz M.C. Ekınlı Lagnünüde yakalanan dere pısısı baliklari (Pleuronectus flesus luscus L. 1758) üzerıne parasitolojik bir araştirma. Turkish Journal of Zoology, 1991, 15, 150-163.

OĞuZ M.C. \& Kvach Y. Occurrence of acanthocephalans in teleost fishes of Gemlik Bay, Sea of Marmara, Turkey. Helminthologia, 2006, 43, 103-108.

Osmanov S.U. Materialy k parazitofaune ryb Chernogo morya. Uchenye Zapiski Leningradskogo gosudarstvennogo pedagogicheskogo instituta im. A.I. Gertsena, Kafedra Zoologii i Darvinizma, 1940, 30, 187-265.

Petrochenko V.I. Akantotsefaly (skrebni) domashnih i dikih zhivotnyh. Volume 1, Izdatelstvo AN SSSR, Moscow, 1956, $431 \mathrm{p}$.

Pichelin S. \& CribB T.H. A review of the Arhythmacanthidae (Acanthocephala), with a description of Heterosentis hirsutus n. sp. from Cnidoglanis macrocephala (Plotosidae) in Australia. Parasite, 1999, 6, 293-302.

Porta A. Gli Echinorinchi dei Perci. Archive Zoologico Italiana, 1905, 2, 149-214.

RǍDulEscu I. Contribuţiuni la cunoaşterea parasitilor peştilor din Marea Neagră ţărmul românesc. Anales Instutului de Cercetari Piscicole Românesc, 1948, 3, 282-309.

RǍdulescu I. \& Angelescu N. Analyses parasitologiques sur le poisson dans le secteur roumain du Delta du Danube. Cercetari Marine, 1973, 5-6, 291-326.
SOLONCHENKo A.I. Gelmintofauna ryb Azovskogo morya. Naukova Dumka, Kiev, 1982, 152 p.

YAMAGuTI S. Acanthocephala, in: Systema Helminthum, Vol. 5, Interscience Pub. John Wiley and Science, New YorkLondon, 1963, 453 p.

Reçu le 28 novembre 2008 Accepté le 14 décembre 2009 